Появились новые подтипы ПТСР со своими критериями: ПТСР у детей 6 лет и моложе (предшкольный подтип ПТСР) и диссоциативный подтип ПТСР. Диагноз диссоциативного подтипа применим к лицам, которые отвечают критериям ПТСР наряду с проявлениями деперсонализации и дереализации.

Таким образом, уточненные и дополненные на современном этапе критерии диагностики развития ПТСР, позволяют более точно и эффективно диагностировать данное травматическое расстройство, связанное с травмой и стрессором.

$$
* * *
$$

1. Бек, А. Когнитивная психотерапия расстройств личности / А. Бек. - СПб.: Питер, 2019. - 448 c.

2. Валентик, Ю.В. Дифференцированная психотерапия пациентов, совершивших аутоагрессивные действия, с учетом их личностных особенностей/ Ю.В.Валентик, И.К. Чобану, Н.М. Епифанова M.: ГЕОС, 2014. $-63 \mathrm{c}$.

3. Водопьянова, Н. Е. Психодиагностика стресса/ Н. Е.Водопьянова. - СПб.: Питер, 2009. - 336 с.

4. Дмитриева, Т.Б. Транзиторные психотические состояния у комбатантов, страдающих посттравматическим стрессовым расстройством/ Т.Б.Дмитриева, Г.В.Василевский, Г.А.Фастовцов // Российский психиатрический журнал. - 2018.- №3. - С.13.

\title{
Меметова 3.
}

\section{Аутодеструктивное поведение при посттравматическом стрессовом расстройстве} Крымский инженерно-педагогический университет. ГБОУ ВО Республики Крым имени Ф. Якубова

doi: 10.18411/lj-06-2020-457

(Россия, Симферополь)

idsp: ljournal-06-2020-457

\section{Аннотация}

В статье рассмотрены конструктивные и деструктивные механизмы преодоления посттравматического стрессового расстройства, дано определение понятиям косвенной и прямой аутодеструкции, определены виды аутодеструктивного поведения у личности с посттравматическим стрессовым расстройством. Так же выявлены когнитивные, эмоциональные и поведенческие особенности аутодеструктивного поведения личности с посттравматическим стрессовым расстройством.

Ключевые слова: посттравматическое стрессовое расстройство, аутодеструкция, аутодеструктивное поведение.

\section{Abstract}

Constructive and destructive mechanisms for overcoming post-traumatic stress disorder are considered, the concepts of indirect and direct auto-destruction are defined, types of self-destructive behavior in a person with post-traumatic stress disorder are determined. Cognitive, emotional and behavioral features of self-destructive behavior of a person with post-traumatic stress disorder were also identified.

Keywords: post-traumatic stress disorder, auto-destruction, auto-destructive behavior.

Существует тесная связь между способами выхода из кризисной ситуации, то есть способами преодоления посттравматического стрессового расстройства, а именно устранения и избегания любых напоминаний о травме, погруженность в работу, алкоголь, наркотики, стремление войти в группу взаимопомощи и т.п. и успешностью последующей адаптации: конструктивные и деструктивные [3].

К деструктивным механизмам преодоления ПТСР относятся: аутодеструктивное поведения, суицидальное поведение и аутоагрессивное поведение индивида, которые часто в психологии употребляются как синонимы. 
Аутодеструктивное поведение является преднамеренным действием либо преднамеренным поступком при неосознавании возможности смертельного исхода как их результата, приводящих к физическому или психическому разрушению личности, которая не ставит осознанно цели лишить себя жизни.

У лиц с ПТСР бывает аутодеструктивное поведение бывает прямым или косвенным. Чтоб рассмотреть подробней каждый вид нужно сперва дать определение данным видам.

Так, прямым аутодеструктнвным поведением является поведение личности, которое направлено на нанесение себе самоповреждений, но при этом без цели «покончить с собой»[1].

Косвенная аутодеструкция это причинение отсроченного вреда собственному здоровью без цели лишения себя жизни, которая в свою очередь может быть разделена на активную (осознаваемую) и пассивную (неосознаваемую) деструкции [3].

Аутодеструктивное поведения у личности с посттравматическим стрессовым расстройством бывает семи видов:

- $\quad$ релаксационное для снятия эмоционального напряжения;

- манипулятивное, проявляется демонстрацией самоповреждений с целью манипуляции ближайшим окружением с целью достижения своей цели;

- инфантильно-демонстративное, проявляется для доказательства любви, самоутверждения либо «на спор»;

- призыв, проявляется нанесением самоповреждений для того, чтоб обратить на себя внимание;

- инфантильно-подражательное, проявляется тем, что подражая более значимым наносятся себе самоповреждения с целью доказательства «силы»;

- инфантильно-мазохистическое, проявляется тем, что человек получает удовольствие от нанесения себе самоповреждений;

- симулятивное, проявляется уклонением от каких-либо обязанностей.

Когнитивными особенностями аутодеструктивного поведения личности с посттравматическим стрессовым расстройством являются:

- Нарушение памяти и концентрации внимания. В некоторых случаях у человека возникают трудности в сосредоточении и упоминании. В спокойном состоянии в исследуемых концентрация внимания может быть очень большой, но при возникновении любого стрессового фактора человек уже не в состоянии сосредоточиться [2].

- Мысли о самоубийстве. Когда человек достигает того предела отчаяния, где он не находит никаких вариантов исправить свое положение, он начинает думать о самоубийстве. Посттравматические пациенты, в том числе и ветераны рассказывают, что некоторое время находились на такой грани.

Эмоциональными особенностями личности с посттравматическим стрессовым расстройством являются:

- Притупленность эмоций. Проявляется тем, что человек полностью или частично теряет эмоциональные проявления.

- Агрессивность, а зачастую встречается также психическая, вербальная и эмоциональная агрессивность.

- Приступы ярости. Как показывают исследования, такие приступы возникают чаще всего под воздействием алкоголя или наркотических веществ. 
- Проявление аффектов, взрывная реакция. При каждой неожиданности человек осуществляет стремительные движения, например падает на землю во время звука вертолета, быстро вращается и принимает боевую позицию, когда кто-то приближается к нему со спины.

- Общая тревожность. Проявляется на физиологическом уровне, болью в спине, спазмами желудка, головной болью. А в психической сфере проявляется постоянным волнением, «параноидальными» явлениями, такими как, например, необоснованный страх преследования. А в эмоциональных волнениях постоянным чувством страха, неуверенности, комплексом вины.

- Депрессия. Данное состояние характеризуется нервным истощением, апатией и негативным отношением к жизни.

К поведенческим особенностям личности с посттравматическим стрессовым расстройством стоит отнести:

- Немотивированная бдительность. В данном случае человек пристально следит за всем, что происходит вокруг. Постоянно ощущает чувство угрозы.

- Склонность к психотизму. Проявляется стремлением решать свои проблемы с помощью грубой силы. Обычно это касается физического силового воздействия.

- Злоупотребление наркотическими и веществами. Чтобы снизить интенсивность посттравматических синдромов, испытуемые, особенно люди которые пережили нахождение в местах боевых действий или принимали непосредственное участие в боевых действиях употребляют алкогольные или наркотические препараты.

- Проявления различных акцентуаций. Возбужденный и застревающий тип акцептуаций характеризуются высоким уровнем соматической и психической немотивированной тревоги на гипотимно окрашенном аффективном фоне с переживанием несколько раз в сутки[5].

Тревожные представления имеют непроизвольный характер, с оттенком навязчивости, и отражают психотравмирующую ситуацию.

Таким образом, можно подытожить аутодеструктнвное поведение, которое иными словами характеризуется как само разрушительное поведение личности с посттравматическим стрессовым расстройством является преднамеренным действием. А именно преднамеренным поступком при неосознавании возможности смертельного исхода как их результата, приводящих к физическому или психическому разрушению личности, которая не ставит осознанно цели лишить себя жизни.

$$
* * *
$$

1. Водопьянова, Н. Е. Психодиагностика стресса/ Н. Е.Водопьянова. - СПб.: Питер, 2009. - 336 с.

2. Дмитриева, Т.Б. Транзиторные психотические состояния у комбатантов, страдающих посттравматическим стрессовым расстройством/ Т.Б.Дмитриева, Г.В.Василевский, Г.А.Фастовцов // Российский психиатрический журнал. - 2018.- №3. - С.13.

3. Забродин Ю.М. Психодиагностика / Забродин Ю.М., Пахальян В.Э.; под общ. ред. Ю.М. Забродина. - М.: Эксмо, 2017. - 448 с.

4. Кочарян, А.С. Психотерапия: Учебник для вузов / Л.Ф. Бурлачук, А.С. Кочарян, М.Е. Жидко; Под общ. и науч. ред. Л.Ф. Бурлачук.. - СПб.: Питер, 2012. - 496 с.

5. Лаукс, Г. Психиатрия и психотерапия: справочник / Г. Лаукс. - М.: МЕДпресс-информ, 2015. - 512 c. 